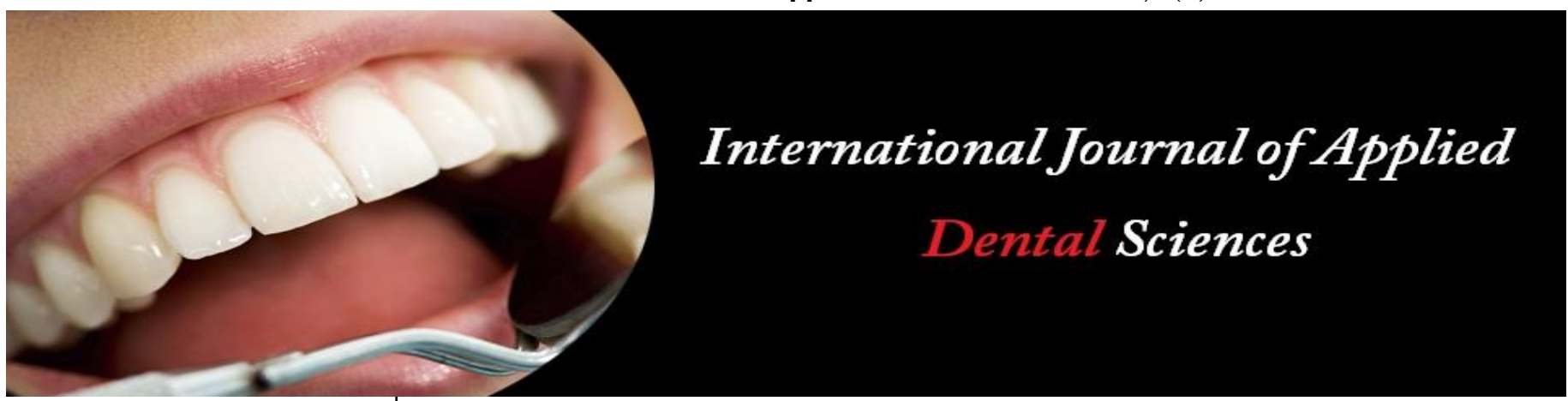

ISSN Print: 2394-7489

ISSN Online: 2394-7497

IJADS 2018; 4(3): 365-370

(C) 2018 IJADS

www.oraljournal.com

Received: 25-05-2018

Accepted: 26-06-2018

\section{Meltem Bakka}

Department of Pediatric

Dentistry, Faculty of Dentistry,

Bezmialem Vakif University,

Turkey

\section{Betul Kargul}

Department of Pediatric

Dentistry, Faculty of Dentistry,

Marmara University, Turkey
Correspondence

Meltem Bakkal

DDS PhD, Department of

Pediatric Dentistry, Faculty of

Dentistry, Bezmialem Vakif

University, Turkey

\section{The differential electrophoretic patterns of statherin and histatins in caries-active and caries-free children}

\section{Meltem Bakkal and Betul Kargul}

\section{Abstract}

Aim: The present study aimed to reveal the possible different protein profiles of children who had cariesactive and caries-free deciduous dentition. Salivary parameters including salivary $\mathrm{pH}$, flow rate, the concentrations of calsium, phosphate and total protein, were also evaluated to see the possible changes in case of dental caries.

Materials and methods: Eight subjects were participated in 'caries-active group' and the other 10 subjects were in 'caries-free group'. Salivary parameters including salivary $\mathrm{pH}$, flow rate and the concentrations of calcium, phosphate and total protein were evaluated in both groups and the electrophoretic patterns for Statherin and Histatins in the groups were analysed by using Discontinuous Native Polyacrylamide Gel Electrophoresis and Basic Gel Electrophoresis; respectively.

Results: The slight differences were observed on the salivary parameters of the groups $(p>0.05)$. Salivary proteins were identified according to their relative mobility in gel and stain patterns. A total of 7 Statherin $(38.8 \%)$ and 3 Histatin $1(16.6 \%)$ bands were counted on the gels. All 3 Histatin 1 bands were seen in only caries-free samples meanwhile 6 of 7 Statherin bands $(33.2 \%)$ were in caries-free samples, as well.

Conclusion: These preliminary findings report that satatherin and histatin1 had different electrophoretic patterns in children with different caries status. Additional studies can provide further evidence concerning the role of each salivary proteins in modifying risk for dental caries.

Keywords: Children, dental caries, gel electrophoresis, histatins, statherin, saliva

\section{Introduction}

Dental caries is a chronic disease characterized by demineralization of tooth structure. The process initiated within only biofilm-covered tooth surfaces by acidic end-products of dietary carbohydrates. The management of dental caries is dependent on the assessment of caries risk because it is preventable and initially reversible ${ }^{[1]}$. Host factors play an important role in caries risk assessment including salivary parameters such as composition and concentration of its organic/inorganic elements and also flow rate of this fluid ${ }^{[2]}$. As the flow rate changes; $\mathrm{pH}$ and the concentrations of organic/inorganic elements, including calcium, phosphate and total protein, change as well ${ }^{[3]}$. The chemical composition of saliva is believed to be associated the presence of tooth decay. Related to this field, there have been numerous attempts to show an association between dental caries and the amount of calcium in saliva ${ }^{[4,5]}$. Fewer studies have considered the phosphorus content as well ${ }^{[6,7]}$.

Saliva is also thought to be a natural protective mechanism against tooth decay ${ }^{[8]}$ because it contains salivary proteins which adsorb strongly onto the teeth, protecting enamel against acid dissolution. This adsorbed protective layer is called acquired enamel pellicle (AEP) and acts as a selective permeable barrier that regulates mineralization/demineralization processes. It also controls the composition of the microbial flora that form dental plaque ${ }^{[9]}$. Recent studies using human whole saliva have shown individual differences in salivary protein patterns $[8,10]$. Genetically determined variations in salivary protein composition may play an important role in the etiology of dental caries and other oral diseases ${ }^{[11]}$. It has thus been agreed that determining salivary protein profiles of children can contribute to the evaluation of caries risk and hence early prevention of this widespread disease ${ }^{[8,10]}$. The in vivo AEP showed significant numbers of histatins (histatin1, 3, and 5) remain intact ${ }^{[12]}$. When histatins are adsorbed onto the enamel surface forming the AEP, these proteins provide protection against acid injury ${ }^{[12]}$. Histatin 1 is a salivary protein that also exhibits antifungal and antibacterial 
activities and has functions include buffering and modulation of mineral formation ${ }^{[13]}$. Similar to Histatins, Statherin is a small molecular weight salivary protein with negative net charges that inhibits both primary and secondary calcium phosphate precipitation ${ }^{[14]}$.

Native Polyacrylamide Gel Electrophoresis (Native PAGE) and Basic gel electrophoresis are the techniques for separating biologically active proteins. In contrast to SDS-PAGE (Sodium dodecyl sulphate- Polyacrylamide Gel Electrophoresis), the mobilities of proteins in a native PAGE and Basic gel systems depend on both size and charge. In electrophoresis, proteins are separated on the basis of charge, and if the electrodes are arranged in such a way that the upper bath is - (cathode), while the lower bath is + (anode), and anions are allowed to flow toward the anode, the system is known as an anionic system (Discontinuous Native PAGE). Flow in the opposite direction is a cationic system (Basic Gel Electrophoresis) and allows + cations to move toward the cathode.

In the present study we aimed to reveal the possible different electrophoretic patterns of salivary proteins; Statherin and Histatins in children having caries-active and caries-free deciduous dentition by using Discontinuous Native-PAGE and Basic Gel Electrophoresis. In addition salivary parameters including salivary $\mathrm{pH}$, flow rate and the concentrations of calcium, phosphate and total protein were evaluated in both groups, as well.

\section{Materials and Methods}

\subsection{Subject selection}

The study protocol was approved by the Research Human Ethics Board of Western University (Review number; 16181E). The caries status of children aged 3-5 years old were assessed according to the International Caries Detection and Assessment System (ICDAS II) criteria. 'Caries-active group' was composed of 8 children having at least two active caries lesions and 'caries-free group' was composed of 10 children having no caries and/or fillings. Children who were participated in the study, were free from systemic or local diseases which affect salivary secretions. Children who have been on medication for the last 3 months that could affect the saliva composition and children who had topical fluoride application in the last 6 months were not included.

\subsection{Saliva collection}

Children were asked to refrain from any consumption of food, beverages and dental hygiene products for at least 1 hour prior to collection time which is necessary for saliva to return to the resting state. Unstimulated whole saliva samples were collected in ice at 9:00-11:00 am to avoid the circadian rhythm effects on saliva composition and flow rate. All procedure was done with the patient comfortably seated in a well-ventilated and lighted room. To standardize the saliva collection from the children aged 3-5 years we used an eppendorf tube and a suction device which creates a negative pressure in the tube, instead of using 'spitting' and/or 'drooling' methods.

\subsection{Salivary Analysis}

The time and volume of collected saliva were recorded to measure the salivary flow rate. Then the collected saliva samples were divided into 2 halves; the half was kept as whole saliva and used for measurement of salivary $\mathrm{pH}, \mathrm{Ca}$ and phosphate concentrations, meanwhile the other half was centrifuged at $14,000 \times g$ for $20 \mathrm{~min}$ and the supernatants were separated from the pellets to use for the determination of total protein concentration. First salivary $\mathrm{pH}$ was measured by $\mathrm{pH}$ metre (SympHony SB70P, VWR, US) with micro $\mathrm{pH}$ electrode (PHR-146, Lazar, CA, USA). Quantitative colometric calcium determination was carried out with QuantiChrom-TM Calcium Assay Kit (DICA-500, BioAssay Systems, Hayward, CA, USA) which was used according to manufacturer's instructions. Phosphate concentration was determined by performing a colometric method (Gee-Deitz) which allows to quantify the color reaction between working reagent and known sample/diluted standard solution $\left(\mathrm{KH}_{2} \mathrm{PO}_{4}\right)$ at the wavelenght $415 \mathrm{~nm}{ }^{[15]}$. Bicinchoninic acid (BCA) protein assay kit with bovine serum albumin standard (Pierce Chemical, Rockford, IL, USA) was carried out to measure the total protein concentration of each subject at $562 \mathrm{~nm}$ (BioRad iMark Microplate Absorbance Reader, CA).

$30 \mu \mathrm{g} / \mu \mathrm{l}$ of whole saliva supernatant for each sample was subjected to Discontinuous Native PAGE by using Statherin $(4 \mu \mathrm{g} / \mu \mathrm{l})$ as standards, and Basic Gel Electrophoresis by using Histatins $(3 \mu \mathrm{g} / \mu \mathrm{l}$ of Histatin 1 , Histatin 3 and Histatin 5$)$ as standards. The concentrations of ingredients for separating and stacking gel solutions were given in Table 1.

Table 1: The used concentrations of separating and stacking gel solutions for Discontinuous Native-PAGE and Basic Gel Electrophoresis

\begin{tabular}{|c|c|c|c|}
\hline \multicolumn{2}{|l|}{ Separating gel solutions; } & \multicolumn{2}{|l|}{ Stacking gel solutions; } \\
\hline \multicolumn{2}{|c|}{ For $10 \mathrm{~mL} 12 \%$ Discontinuous Native PAGE } & \multicolumn{2}{|c|}{ For 10 mL Discontinuous Native PAGE } \\
\hline Distilled deionized water & $3.500 \mathrm{~mL}$ & Distilled deionized water & $3.500 \mathrm{~mL}$ \\
\hline Acrylamide/BIS (30\%) & $4.000 \mathrm{~mL}$ & Acrylamide/BIS (30\%) & $4.000 \mathrm{~mL}$ \\
\hline Tris-HCl $1.5 \mathrm{M} \mathrm{pH} 8.8$ & $2.500 \mathrm{~mL}$ & Tris-HCl $1.5 \mathrm{M} \mathrm{pH} 8.8$ & $2.500 \mathrm{~mL}$ \\
\hline APS $10 \%(\mathrm{w} / \mathrm{v})$ & $0.050 \mathrm{~mL}$ & APS $10 \%(\mathrm{w} / \mathrm{v})$ & $0.050 \mathrm{~mL}$ \\
\hline TEMED & $0.005 \mathrm{~mL}$ & TEMED & $0.010 \mathrm{~mL}$ \\
\hline \multicolumn{2}{|c|}{ For Basic Gel Electrophoresis } & \multicolumn{2}{|l|}{ For Basic Gel Electrophoresis } \\
\hline Acrilamide/BIS (30\%) & $2.000 \mathrm{~mL}$ & Acrilamide/BIS (30\%) & $0.500 \mathrm{~mL}$ \\
\hline $\begin{array}{l}0.5 \text { g Amonyum persulphate, } \\
9 \text { mg Riboflavin } 5 \text { 'phosphate } \\
\text { Final volume } 5 \mathrm{~mL} \\
\end{array}$ & $0.015 \mathrm{~mL}$ & $\begin{array}{l}24 \mathrm{~mL} 1 \mathrm{~N} \mathrm{KOH}, 22.5 \mathrm{~mL} \text { distilled water, } 0.5 \mathrm{~mL} \\
\text { TEMED. pH 5.9 (adjusted with glacial asetic acid) }\end{array}$ & $0.500 \mathrm{~mL}$ \\
\hline $\begin{array}{c}12 \mathrm{~mL} 1 \mathrm{M} \mathrm{KOH}, \\
12.5 \mathrm{~mL} \text { distilled water, } \\
120 \mu \mathrm{L} \text { TEMED, } \\
25 \mathrm{~mL} \text { glacial asetic acid. } \\
\text { pH } 2.74 \text { (adjusted with } 45 \% \mathrm{KOH} \text { ) }\end{array}$ & $2.000 \mathrm{~mL}$ & $\begin{array}{c}10 \mathrm{~g} \text { sucroz } \\
\text { Final volume } 25 \mathrm{~mL} \\
\text { Distilled water } \\
4 \mathrm{mg} \text { Riboflavin 5'phosphate (final volume } 50 \mathrm{~mL} \text { ) }\end{array}$ & $\begin{array}{l}2.000 \mathrm{~mL} \\
0.500 \mathrm{~mL} \\
0.500 \mathrm{~mL}\end{array}$ \\
\hline
\end{tabular}

\subsection{Statistical analysis}

The gels were scanned (FX- Bio-Rad, Hercules, CA, USA), and statistical analysis was performed using a commercially available software program IBM SPSS Statistics 22 (IBM SPSS, Turkey). Student's t test was used to compare the groups. Statistical significance was accepted for $\mathrm{p}<0.05$. 


\section{Results and Discussion}

Eighteen children (10 girls, 8 boys) aged 3-5 years old (mean $\pm \mathrm{SD} ; 46.8 \pm 9.5$ months) participated in this study. We collected unstimulated whole saliva to eliminate the differences in the compositions of each gland's secretions when they are stimulated ${ }^{[16]}$.

The slight differences were observed on the concentrations of calcium $(5.98 \pm 1.38 \mathrm{mg} / \mathrm{dL}$ in caries-free group; $6.01 \pm 1.32$ $\mathrm{mg} / \mathrm{dL}$ in caries-active group) and phosphate $(4.33 \pm 1.24 \mathrm{mM}$ in caries-free group; $5.92 \pm 2.26 \mathrm{mM}$ in caries-active group) between the groups, but these differences were not statistically significant (Table 2). In addition to saliva's protective role mediated by its ability to clear cariogenic substances from the mouth, saliva is also the primary resource of calcium and phosphate which are necessary to remineralize the enamel. But, conflicting results have been obtained from the studies investigating the calcium and phosphate contents of saliva and their relations to dental caries [7, 17, 18]. The present study showed that the salivary calcium concentration in caries active group was higher than which was found in caries free group, but the difference was not significant. Horton et al. analyzed saliva samples of several hundred children with varying numbers of carious teeth, and then reported that as the number of carious teeth increases, the calcium concentration of the saliva decreases ${ }^{[19]}$. They also observed higher salivary calcium concentrations at the early stages of caries development. Because in our study, cariesactive group were mostly composed of white spots lesions which are the initial step of dental caries, thus lead us to suggest that the higher calcium levels found in our caries active group might be due to the high number of white spot lesions presented in the children with caries-active dentition.

In the studies with phosphorus levels of the saliva, Hawkins found lower levels in caries free individuals than for those who were susceptible to caries, while Karshan et al. found it higher in caries-free group ${ }^{[20,21]}$. In the present study we did not found any statistical differences between the groups. The limited study population of the present study was the most likely the reason for the lack of differences.

The saliva flow rates and salivary $\mathrm{pHs}$ in both groups were shown in Table 2 with statistical $p$ values. The outcome of the present study showed that unstimulated whole saliva $\mathrm{pH}$ had a weak correlation with caries activity. An increase in the salivary flow rate was observed among both the groups with a decreased protein concentration indicating an inverse relationship between the salivary flow rate and protein concentration due to the protein dilution levels in saliva (Figure 1). However higher total protein concentration was found with lower salivary pHs (Figure 2). Similar results with the present study were seen in the studies conducted by Birkhed ${ }^{[22]}$ and Heintze ${ }^{[23]}$ showing that no correlation was found between salivary flow rate and caries activity. However in the studies of Browne et al. ${ }^{[24]}$ and Scully ${ }^{[25]}$, it was shown that dental caries is probably the most common consequence of hypo-salivation. Because the normal range of saliva flow can be very large and may include individuals with very slow flow rates who do not have any problems like dry mouth ${ }^{[26]}$, it can be suggested that the measurement of salivary flow rate would provide valuble meanings when it was measured at appropriate intervals.

Table 2: Salivary parameters in caries free and caries active children

\begin{tabular}{|c|c|c|c|c|c|}
\hline & Flow rate (mL/min) & Salivary pH & Phosphate $(\mathbf{m M})$ & Total protein $(\boldsymbol{\mu g} / \mathbf{m L})$ & Calcium $(\mathbf{m g} / \mathbf{d L})$ \\
\hline Caries-Free & $0.359 \pm 0.20$ & $7.15 \pm 0.15$ & $4.33 \pm 1.24$ & $647.85 \pm 159.92$ & $5.98 \pm 1.38$ \\
\hline Caries-Active & $0.455 \pm 0.24$ & $7.03 \pm 0.38$ & $5.92 \pm 2.26$ & $782.10 \pm 240.02$ & $6.01 \pm 1.32$ \\
\hline $\mathrm{p}$ & 0.207 & 0.389 & 0.389 & 0.389 & 0.324 \\
\hline
\end{tabular}

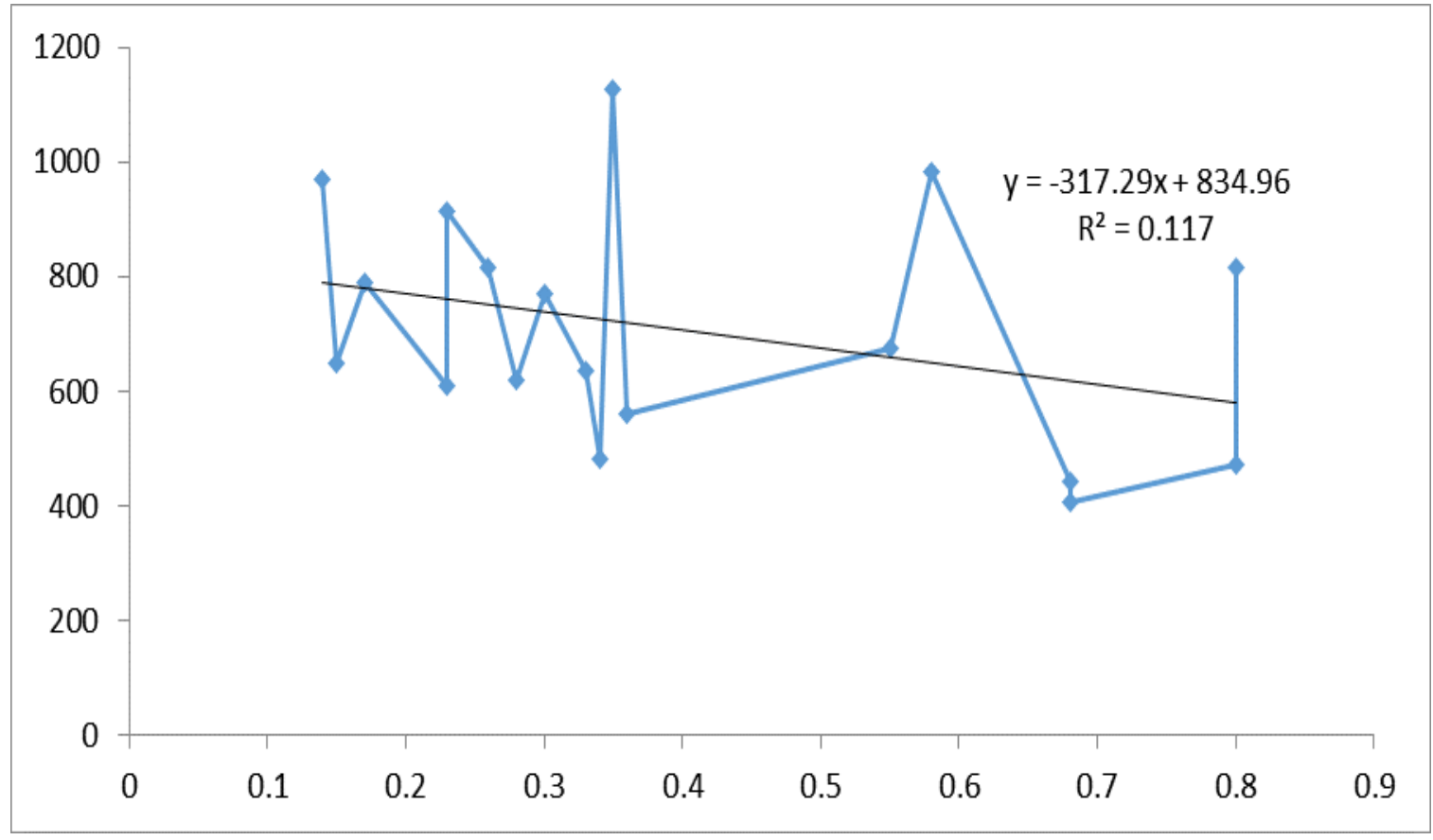

Fig 1: The association between total protein concentration $(\mu \mathrm{g} / \mathrm{mL})$ and saliva flow rate $(\mathrm{mL} / \mathrm{min})$ of 18 samples 


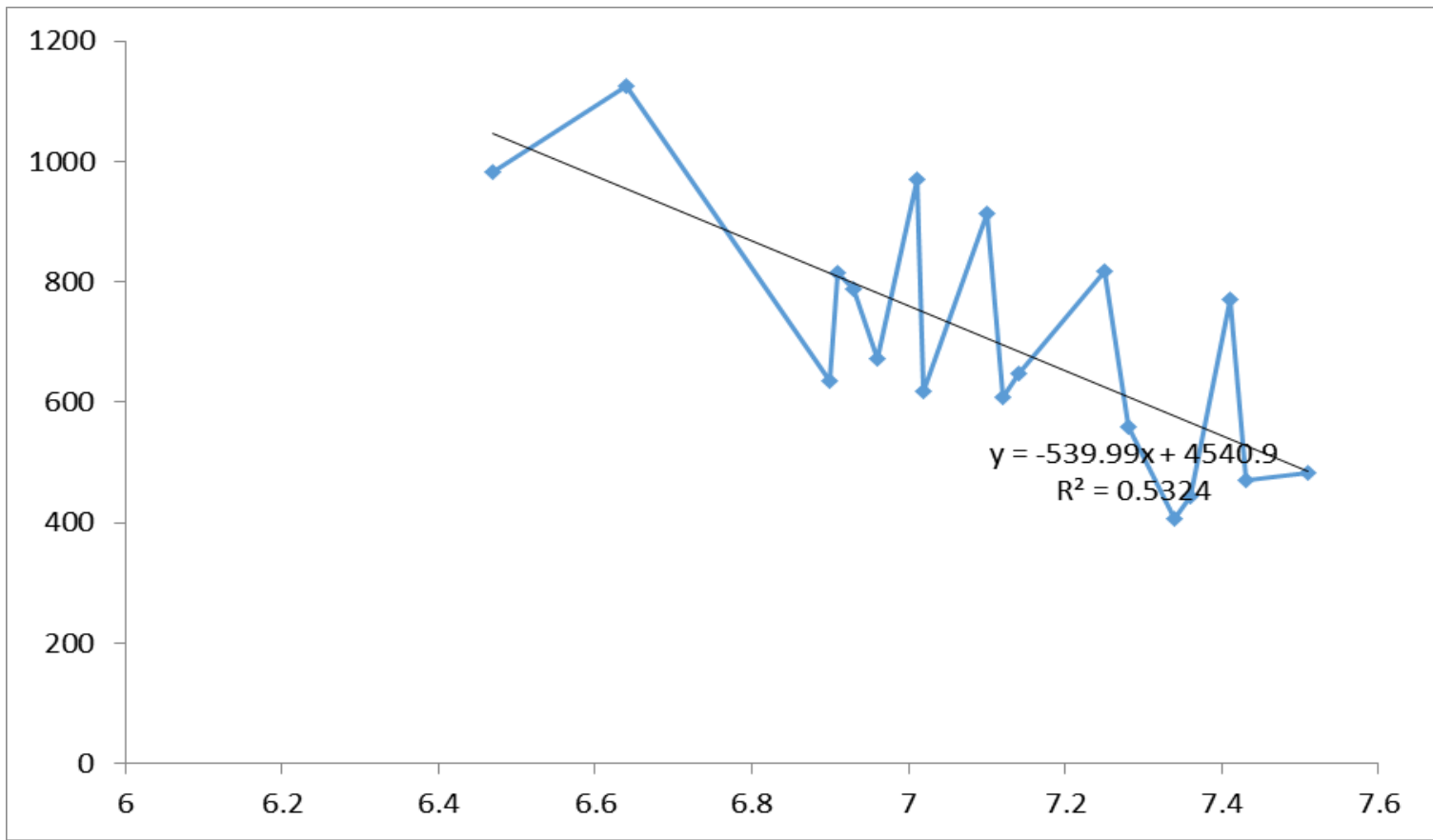

Fig 2: The association between total protein concentration $(\mu \mathrm{g} / \mathrm{mL})$ and salivary $\mathrm{pH}$

The total protein concentrations of the groups presented different protein profiles $(647.85 \pm 159.92 \mu \mathrm{g} / \mathrm{mL}$ in cariesfree group; $782.10 \pm 240.02 \mu \mathrm{g} / \mathrm{mL}$ in caries-active group). These results are similar to Vitorino et al., who found a higher number of total protein concentration in caries active group [27]. It was suggested that increased proteolytic activity or decreased anti-proteolytic processes of caries-active individuals could be associated with higher protein concentration found in caries-active group. Therefore the higher protein concentration with a lower $\mathrm{pH}$ level in saliva of caries-active children would be a protective response of the body. We also observed an inverse association between the salivary flow rate and protein concentration. These results were consistent with the reports of Cohen et al. ${ }^{[28]}$ and Bhalla et al. ${ }^{[29]}$ who had explained an increase in salivary flow rates resulting in decreased protein concentrations due to protein dilution in saliva.

Dental caries is one the most common chronic diseases throughout the lifetime ${ }^{[30]}$. This condition is regulated by multifactorial factors as example, salivary proteins. During the past years important studies have been made in the separation and characterization of the salivary proteins by using the technique of electrophoresis on polyacrylamide gel. Saliva is a complex oral fluid contains a wide spectrum of proteins, namely, amylase, mucins, histatins, statherin, proline-rich proteins and others ${ }^{[9]}$. Some of these proteins have shown to be affected in maintaining the health of oral cavity and there have been many studies attempting to relate dental caries and salivary proteins ${ }^{[31,32]}$. Therefore in the current study we analysed saliva samples with different gel matrix buffers and electric currents by using Discontinous Native-PAGE and Basic Gel Electrophoresis to see the electrophoretic patterns of differently charged proteins; Statherin and Histatins. According to our results, Statherin and Histatin 1 bands were seen in caries free samples with a high trend. Salivary proteins were identified according to their relative mobility in gel and stain patterns. The number of bands presented for each subject was counted on the gels according to the band size and stain intensity as absent, present, and high intensity and size (Figure 3 and 4). In the Discontinuous Native PAGE and Basic Gel Electrophoresis salivary proteins were scored only as present and absent. According to the presence or absence of stains, a total of 7 Statherin bands $38.8 \%$, analysed by Discontinuous Native PAGE) and 3 Histatin1 bands (16.6\%, analysed by Basic Gel Electrophoresis) were counted in all samples. But Statherin bands were scored as $60 \%$ in caries-free samples whereas $12.5 \%$ in caries-active samples. In addition, Histatin 1 bands were scored as $30 \%$ in only caries-free samples (Table 3). Statherin and histatins are known as the precursor proteins of acquired enamel pellicle which regulates mineralization/demineralization processes. Statherin has various functions as binding with high selectivity to hydroxyapatite and promote crystal inhibition of supersaturated calcium and phosphate in saliva, that in turn facilitates enamel remineralization ${ }^{[33]}$. It also has functions on the colonisation of initial microbial layer on tooth surface ${ }^{[14]}$. Similar to statherin, histatins are salivary proteins that are adsorbed onto the enamel surface to form the AEP [12]. In addition, histatins when adsorbed onto the enamel surface provide protection against acid injury. Our results support the studies emphasizing those Statherin is determinant of initial microbial colonization of tooth surface and histatins have functions as antifungal and antibacterial in vivo ${ }^{[34,35]}$.

Table 3: The distribution of bands counted in gels according to groups

\begin{tabular}{|c|c|c|c|}
\hline & $\begin{array}{c}\text { Caries-free samples } \\
\text { (10 subjects) }\end{array}$ & $\begin{array}{c}\text { Caries-active samples } \\
\text { (8 subjects) }\end{array}$ & $\begin{array}{c}\text { Total } \\
\text { 18 subjects }\end{array}$ \\
\hline Statherin & 6 bands $(60 \%)$ & 1 band $(12.5 \%)$ & 7 bands $(38.8 \%)$ \\
\hline Histatin1 & 3 bands $(30 \%)$ & - & 3 bands $(16.6 \%)$ \\
\hline
\end{tabular}




\section{Conclusion}

Although these findings are preliminary, we suggest that there is a kind of trend in electrophoretic patterns of Statherin and Histatin1 in case of dental caries. Further information on molecular epidemiology of salivary proteins may support the use of this methodology as a diagnostic tool in dental caries and other oral health problems. At this time, the data generated herein is extremely relevant to the foundation for the new diagnosis and prevention methods of dental caries by detection and quantification of a single biomarker.

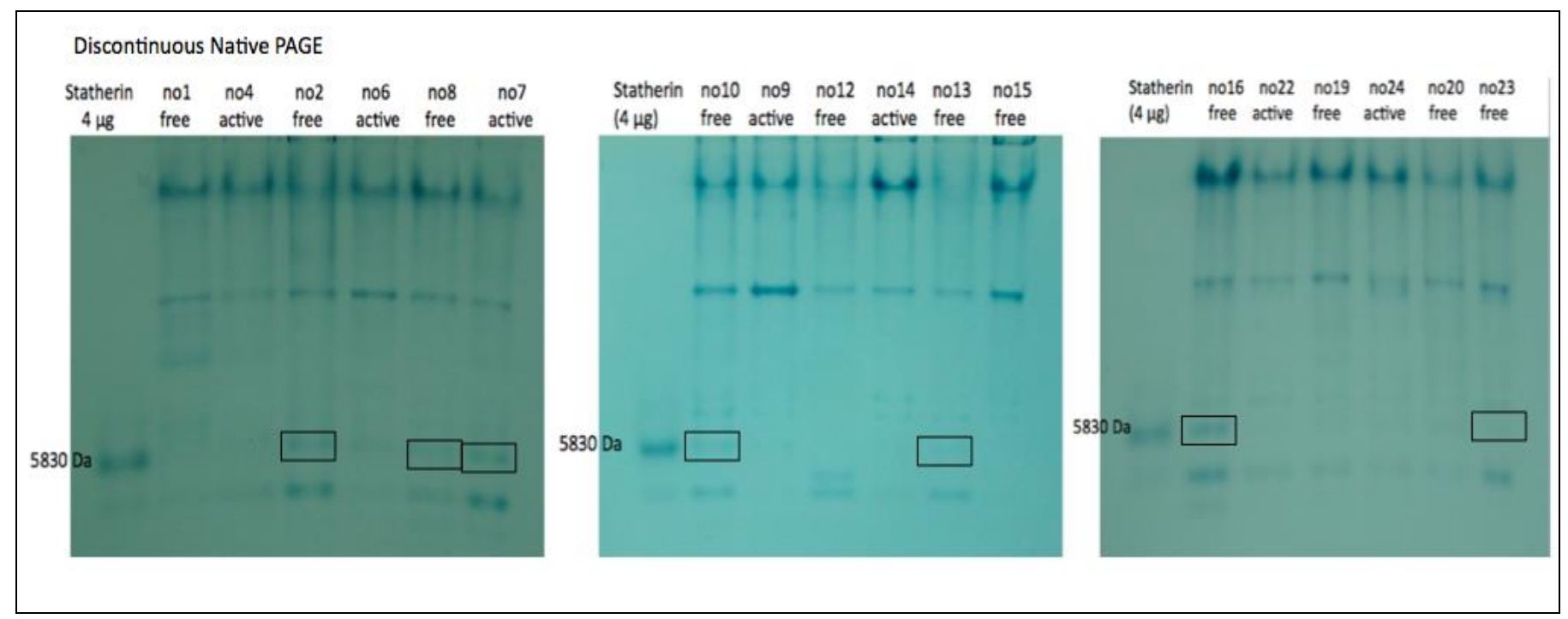

Fig 3: Gel and stain patterns of Discontinuous native - PAGE; Statherin bands presented with rectangular frames, were seen in 6 caries-free and 1 caries-active samples

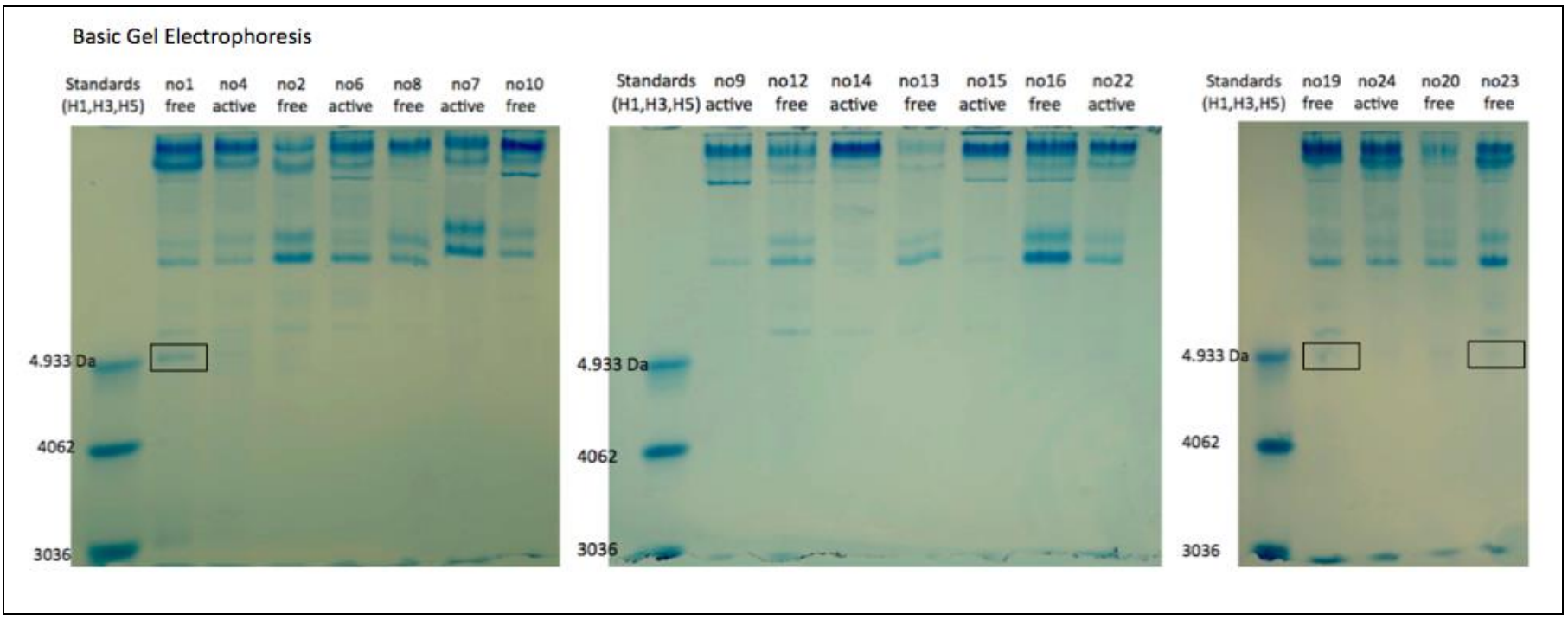

Fig 4: Gel and stain patterns of Basic Gel Electrophoresis; Histatin1 bands presented with rectangular frames, were seen in only 3 caries-free samples

\section{Acknowledgments}

Meltem Bakkal would like to thank Prof Walter Siqueira for sharing his knowledge and being a kind supervisor during her visit to the Western University.

\section{References}

1. Harris R, Nicoll AD, Adair PM, Pine CM. Risk factors for dental caries in young children: a systematic review of the literature. Community Dent Health. 2004; 21(1 Suppl):71-85.

2. Lenander-Lumikari M, Loimaranta V. Saliva and dental caries. Adv Dent Res. 2000; 14:40-7.

3. Miura H, Isogai E, Hirose K, Wakizaka H, Ueda I, Ito N. Application of a sucrose indicator strip to evaluate salivary sucrose clearance. J Dent. 1991; 19(3):189-91.

4. Hay DI, Schluckebier SK, Moreno EC. Equilibrium dialysis and ultrafiltration studies of calcium and phosphate binding by human salivary proteins. Implications for salivary supersaturation with respect to calcium phosphate salts. Calcif Tissue Int. 1982; 34(6):531-8.

5. Lagerlof F. Effects of flow rate and $\mathrm{pH}$ on calcium phosphate saturation in human parotid saliva. Caries Res. 1983; 17(5):403-11.

6. Shahrabi M, Nikfarjam J, Alikhani A, Akhoundi N, Ashtiani M, Seraj B. A comparison of salivary calcium, phosphate, and alkaline phosphatase in children with severe, moderate caries, and caries free in Tehran's kindergartens. J Indian Soc Pedod Prev Dent. 2008; 26(2):74-7.

7. Ashley FP, Wilson RF. The relationship between calcium and phosphorus concentrations of human saliva and dental plaque. Arch Oral Biol. 1978; 23(2):69-73.

8. Sreebny LM, Zhu WX. The use of whole saliva in the 
differential diagnosis of Sjogren's syndrome. Adv Dent Res. 1996; 10(1):17-24.

9. Van Nieuw Amerongen A, Bolscher JG, Veerman EC. Salivary proteins: protective and diagnostic value in cariology? Caries Res. 2004; 38(3):247-53.

10. Schwartz SS, Zhu WX, Sreebny LM. Sodium dodecyl sulphate-polyacrylamide gel electrophoresis of human whole saliva. Arch Oral Biol. 1995; 40(10):949-58.

11. Rudney JD. Does variability in salivary protein concentrations influence oral microbial ecology and oral health? Crit Rev Oral Biol Med. 1995; 6(4):343-67.

12. Abbasi Z, Bahrololoum ME, Bagheri R, Shariat MH. Characterization of the bioactive and mechanical behavior of dental ceramic/sol-gel derived bioactive glass mixtures. J Mech Behav Biomed Mater. 2016; 54:115-22.

13. Akova M, Paesmans M, Calandra T, Viscoli C. A European Organization for Research and Treatment of Cancer-International Antimicrobial Therapy Group Study of secondary infections in febrile, neutropenic patients with cancer. Clin Infect Dis. 2005; 40(2):239-45.

14. Ahmadi-Motamayel F, Goodarzi MT, Hendi SS, Kasraei S, Moghimbeigi A. Total antioxidant capacity of saliva and dental caries. Med Oral Patol Oral Cir Bucal. 2013; 18(4):e553-6.

15. G A. Determination of Phosphate by Differential Spectrophotometry. Anal Chem. 1953; 25(9):4.

16. Sreebny LM. Saliva in health and disease: an appraisal and update. Int Dent J. 2000; 50(3):140-61.

17. Turtola L. [Dental caries and its prevention]. Proc Finn Dent Soc. 1978; 74(1-2):36-7.

18. M. K. Factors in saliva correlated with dental caries. J Dent Res 1939; 18:12.

19. Horton K, Marrack J, Price I. The relation of calcium in the saliva to dental caries. Biochem J. 1929; 23(5):10758.

20. M K. J Dent Res. 1931, 11.

21. HF H. J Dent Res. 1931, 11.

22. Birkhed D, Edwardsson S, Andersson H. Comparison among a dip-slide test (Dentocult), plate count, and Snyder test for estimating number of lactobacilli in human saliva. J Dent Res. 1981; 60(11):1832-41.

23. Heintze U, Birkhed D, Bjorn H. Secretion rate and buffer effect of resting and stimulated whole saliva as a function of age and sex. Swed Dent J. 1983; 7(6):227-38.

24. Browne RW, Kantarci A, LaMonte MJ, Andrews CA, Hovey KM, Falkner KL et al. Performance of multiplex cytokine assays in serum and saliva among communitydwelling postmenopausal women. PLoS ONE. 2013; 8(4):e59498.

25. Scully C. The role of saliva in oral health problems. Practitioner. 2001; 245(1627):841-2, 5-8, 50 passim.

26. Edgar WM. Saliva and dental health. Clinical implications of saliva: report of a consensus meeting. $\mathrm{Br}$ Dent J. 1990; 169(3-4):96-8.

27. Vitorino R, de Morais Guedes S, Ferreira R, Lobo MJ, Duarte J, Ferrer-Correia AJ et al. Two-dimensional electrophoresis study of in vitro pellicle formation and dental caries susceptibility. Eur J Oral Sci. 2006; 114(2):147-53.

28. Cohen RE, Aguirre A, Neiders ME, Levine MJ, Jones PC, Reddy MS et al. Immunochemistry and immunogenicity of low molecular weight human salivary mucin. Arch Oral Biol. 1991; 36(5):347-56.

29. Bhalla S, Tandon S, Satyamoorthy K. Salivary proteins and early childhood caries: A gel electrophoretic analysis. Contemp Clin Dent. 2010; 1(1):17-22.

30. Pitts NB. Are we ready to move from operative to nonoperative/preventive treatment of dental caries in clinical practice? Caries Res. 2004; 38(3):294-304.

31. Rudney JD, Staikov RK, Johnson JD. Potential biomarkers of human salivary function: A modified proteomic approach. Arch Oral Biol. 2009; 54(1):91-100.

32. Al Kawas S, Rahim ZH, Ferguson DB. Potential uses of human salivary protein and peptide analysis in the diagnosis of disease. Arch Oral Biol. 2012; 57(1):1-9.

33. Hay DI. The interaction of human parotid salivary proteins with hydroxyapatite. Arch Oral Biol. 1973; 18(12):1517-29.

34. Edgerton M, Koshlukova SE. Salivary histatin 5 and its similarities to the other antimicrobial proteins in human saliva. Adv Dent Res. 2000; 14:16-21.

35. Gibbons RJ, Hay DI. Human salivary acidic proline-rich proteins and statherin promote the attachment of Actinomyces viscosus LY7 to apatitic surfaces. Infect Immun. 1988; 56(2):439-45. 